\title{
Boncuklu Tarla Doğu Alanı Çanak Çömleksiz Neolitik Dönem Mimarisi ve Köy-Mekan Organizasyonu
}

\section{Bahattin IPEK, Yunus ÇiFTÇi}

Öz

Yukarı Dicle Havzası Neolitik Dönem üzerine olan bilgilerimiz son yıllarda gerçekleştirilen arkeolojik kazılar sayesinde giderek artmaktadır. Mardin ili Dargeçit İlçesi'ne bağlı olan Ilısu Barajı'na ismini veren Ilısu Köyü sınırları içerisinde bulunan Boncuklu Tarla yerleşimi Yukarı Dicle Havzası ÇanakÇömleksiz Neolitik Dönem mimarisi üzerine önemli bilgiler vermektedir. Boncuklu Tarla Doğu Alanı'nda tespit edilen "Kamu Binası" ve etrafında bulunan binalar hem konut ve kamu mimarisi hem de dönemin köy-mekan organizasyonları hakkında önemli bilgiler vermektedir. Özellikle 4b tabakasına ait Kamu Binası ve binanın etrafından bulunan konutlar dönemin köy-mekan organizasyonlarının incelemesi için ayrı bir önem taşımaktadır. Bu binalarda ortaya çıkarılan buluntular, mezarlar ve farklı tipteki duvar teknikleri bahsi geçen dönemin hem Yukarı Dicle hem de Güneydoğu Anadolu Bölgesi açısından zenginliği ön plana çıkarmaktadır. Bu bölgede aynı döneme ait kazıları yapılan yerleşimlerle hem farklılıkları hem de benzerlikleri olan Boncuklu Tarla'daki Doğu Alan yapıları, Boncuklu Tarla içinde de farklı bir öneme sahiptir. 3 Kamu Binası ile birlikte bölgedeki diğer anıtsal yapılara oranla farklı bir öneme sahiptir. Her ne kadar Boncuklu Tarla Doğu Alanı kazıları 2017 ve 2019 yılı olmak üzere iki kazı sezonu olsa da verdiği bilgiler sayesinde Çanak-Çömleksiz Neolitik Çağ’da çok önemli verilere ulaşılmasına olanak sağlamıştır. Mardin ili ve bölgenin tarihi için önemli bilgiler veren Boncuklu Tarla kazıları hem Mardin tarihini günümüzden 12.000 yıl öncesine kadar geri götürmüş hem de o dönemde bölgede yaşayan halklar için de önemli veriler vermiştir. Ayrıca yerleşim yerinin yaklaşık olarak 2000 yıl boyunca kullanılması bize yerleşim yerinin bölge tarihi için ne kadar önemli olduğunu göstermektedir. Bu nedenlerden dolayı Boncuklu Tarla Doğu Alanı mimarisi ve verileri Boncuklu Tarla yerleşiminin Yukarı Dicle Havzası ve Mardin bölgesinin tarihi için ne kadar önemli bir yere sahip olduğunu göstermektedir.

1 Arş. Gör. Bahattin İpek, Mardin Artuklu Üniversitesi Edebiyat Fakültesi Arkeoloji Bölümü, bahattinipek47@gmail.com, naramsin47@hotmail.com, ORCiD ID: 0000-0003-4380-9283.

2 Doktora Öğrencisi Yunus Çiftçi, Van Yüzüncü Yıl Üniversitesi Edebiyat Fakültesi Arkeoloji Bölümü, cftc.yns@gmail.com, ORCiD ID: 0000-0001-5547-7613. 
Anahtar Kelimeler: Yakındoğu Neolitik Dönem, Yukarı Dicle Havzası, Kuzey Mezopotamya Neolitik Dönem, Boncuklu Tarla, Neolitikleşme, Epipaleolitik, PPNA, PPNB, Kamu Yapısı (Stelli Yapı), Köy-Mekan Organizasyonu

\title{
Pre-Pottery Neolithic Period Architecture of Eastern Area of Boncuklu Tarla and Village-Space Organization
}

\begin{abstract}
Our knowledge of the Upper Tigris Basin on the Neolithic Period has been increasing gradually by means of the archaeological excavations carried out in recent years. Boncuklu Tarla settlement, which is in Mardin Province's Dargeçit District, located in the borders of the Ilısu Village which gives its name to llisu Dam, presents substantial information about the Pre-Pottery Neolithic Period architecture of the Upper Tigris Basin. The Public Building identified in the East Area of the Boncuklu Tarla and the buildings around it provide important information about both the residential and public architecture and the village-space organizations of the period. Especially the public building belonging to level $4 \mathrm{~b}$ and the structures around the building bear special importance for the examination of village-space organizations of the period. The finds, graves and different types of wall techniques unearthed in the these buildings highlight the wealth of the period in terms of both the Upper Tigris valley and the Southeastern Anatolia Region. The Eastern Area structures in the Boncuklu Tarla, which have both differences and similarities with the excavated settlements in the same period in this region, have a different importance in the Boncuklu Tarla, too. The three Public Buildings, along with other monumental structures and the unique Public Building with four stele and niche, have a different importance compared to other monumental structures in the region. Although the Boncuklu Tarla East Area excavations have two excavation seasons in 2017 and 2019, it has enabled us to reach very important data for the Pre-Pottery Neolithic Period. The Boncuklu Tarla excavations provide important information for the province of Mardin and the region's history and take the history of Mardin back to 12,000 years ago and give important data for the people living in the region at that time. In addition, the use of the settlement for approximately 2000 years shows us how the this settlement is important for the history of the region. For these reasons, the Boncuklu Tarla Eastern Area architecture and data show how the Boncuklu Tarla has importance for the history of the Upper Tigris Basin and the Mardin region.
\end{abstract}

Keywords: The Near-East Neolithic Period, The Upper Tigris Basin, The Northern Mesopotamia Neolithic Period, The Boncuklu Tarla, The Neolithization, Epipaleolithic Period, PPNA, PPNB, Public Building (Stele Building), Village-space Organization. 


\section{Extended Abstract}

Our knowledge of the Neolithic Period of the Upper Tigris Basin has been increasing over the last 20 years thanks to the identification and excavation of settlements during the archaeological surveys conducted within the scope of the Ilisu Dam and HES Project. Although only three excavation seasons $(2012,2017,2019)$ have been carried out so far, Boncuklu Tarla provides important information not only about the Mardin region but also the history and socio-cultural structure of the Pre-Pottery Neolithic period. The studies and the $\mathrm{C} 14$ analysis at Boncuklu Tarla indicate that the settlement has been inhabited by six different Levels from Late Epipalaeolithic to Late PPNB: Level 1: Late PPNB; Level 2: Middle PPNB; Level 3: Early PPNB; Level 4: transition PPNA-PPNB: Level 5: PPNA; Level 6; Late Epipalaeolithic. Boncuklu Tarla was first identified and investigated by two different teams in 2008 as a result of the surveys carried out within the scope of the studies for Documenting and Rescuing Cultural Heritage Remaining in the llısu Dam and HES Project Interaction Area in the Mardin region. But, the site was excavated in 2012, 2017 and 2019. During the excavations, different architectural remains, skeletal remains, beads, pendants, bone tools, grinding stone and chipped stone finds were unearthed from the Late Epipalaeolithic Period to the end of the Late PPNB Period. The substantial amount of chipped stone tools found in Boncuklu Tarla show significant variation in terms of both typology and technology. Although obsidian fragments are found at the site, flint stone tolls dominate. During the excavations in 2017 and 2019, 130 individuals from 70 graves were exposed. As a result of the excavations, all the graves are inside the houses and single or multiple burials belonging to different individuals. These primary inhumations were intramural in nature and consisted of subadults and adults of both sexes. In addition, three secondary burials were recorded, as well as the skulls of nine individuals unearthed in seven different graves suggestive of the "skull cult" seen elsewhere in the Neolithic Near East. Most of the burials were buried with different types of grave finds, especially beads. Thanks to the graves found as a result of excavations, important information was obtained about Pre-Pottery Neolithic Period burial traditions. When we look at decorative objects in the Boncuklu Tarla, they consist beads, pendants, bracelets, belt buckles, bone plaques, earrings and figured stone objects. Most of the beads were made of serpentine, limestone, chlorite, sandstone, bone, obsidian, malachite and various pebble stones. Animal-shaped beads are common, especially beads (pendants) with bull's heads, deer, leopard, wild goat heads and beads with snake, bird and scorpion shapes. During the excavation, it is possible to mention about at least 6 levels of architectural levels were recovered at the site. Cellplanned structures, grid-planned structures, Terrazzo Building, Public Building (Stele Building) constitute different architectural structures as a result of excavations. The Public Building identified in the East Area (level 4b) of the Boncuklu Tarla and the buildings around it provide important information about both the residential and public architecture and the village-space organizations of the period. 


\section{Giriş}

Yakındoğu Neolitikleşme sürecinde anıtsal binalar dönemin sosyo-kültürel ve sosyo-ekonomik yapıların incelenmesi için önemli bir yere sahiptir (Kodaş, 2013; Özdoğan, 2018; Stordeur, 2014). Söz konusu bu yapılar Neolitik Dönem yerleşim yerlerinin köy-mekan organizasyonlarının oluşumunda belirleyici etken olmuşlardır. Bu tür yapıların incelenmesinde veya sınıflandırılması kapsamında Kamu Binası (Public Building) terimi daha tarafsız bir tanımlama olarak kabul görmekle birlikte (Kodaş, 2013; Rosenberg, 2011; Stordeur, 2014;), özel, anıtsal, tapınak veya megalitik gibi farklı tanımlamalar da bu tür özel yapılar için kullanılmaktadır (Aurenche ve Kozlowski, 2000; Hauptmann, 2011; Özdoğan, 2018; Schmidt, 2011; Watkins, 2006; Yartah, 2013). Güneydoğu Anadolu Bölgesi Çanak Çömleksiz Neolitik Çağ merkezlerine bakıldığında bu tür “Kamu Yapılarını” görmek mümkündür. Ancak bu yapıların çoğunlukla tek amaç için kullanıldığı düşünülmüş ve bu sebeple çoğunlukla belli bir kategori içinde değerlendirilmiştir. Bu tür yapılar genellikle "Kült Yapıları" veya "Dini Yapılar" olarak değerlendirilmiştir (Bknz Schmidt, 2007; Türkcan, 2006). Örneğin, yapılan kazılar sonucunda Göbekli Tepe (Schmidt, 2007) ve Nevali Çori'deki anıtsal yapıların içinden taş heykeller, steller, ve Kült Yapısı II'de ocak taşından çamurla örülmüş mekanı içten çevreleyen bir seki ve Kült Yapısı III'te taş levhalarla kaplı seki bulunmuştur (Hauptmann, 2007). Kazıcıları tarafından bu buluntular dini veya ritüel amaçlı buluntular olarak nitelendirilmişlerdir. Fakat bu iki merkez dışında Boncuklu Tarla başta olmak üzere Güsir Höyük (Karul, 2011; 2013), Hasankeyf Höyük (Miyake ve diğ., 2012; Miyake, 2013), Hallan Çemi, Tell Abr 3 (Yartah, 2013), Jerf El Ahmar (Stordeur, 2014), Mureybet (Stordeur ve Ibáñez, 2008), Nemrik 9 (Kozlowski ve Kempisty, 1990) gibi birbirinden farklı merkezlerde ortaya çıkarılan “Anıtsal (Kamu) Yapıları" için bu bulgular oldukça sınırlıdır. Ayrıca Yukarı Dicle Havzasında bulunan Hasankeyf Höyük (Miyake ve diğ., 2012; Miyake, 2013), Güsir Höyük (Karul, 2011; Karul, 2013) ve Hallan Çemi (Rosenberg, 1995; Rosenberg, 1998; Rosenberg, 2007; Rosenberg, 2011; Rosenberg ve Davis, 1992) gibi merkezlerde ortaya çıkarılan Kamu yapılarında havanelleri, öğütme taşları, dilgi ve dilgicik gibi buluntulara rastlanmıştır. Kuşkusuz günlük yaşama ait genelde 3-5 metreye arasında ebatları olan konutlarda ailelerin yaşadığı düşünüldüğünde, 10.00 metreye varan büyüklükteki yapıların yerleşimlerde farklı işlevleri olduğu kesindir. Fakat bu denli büyük ölçekli yapıların tek bir olgu (Din, Kült) üzerinden değerlendirilmesi yanlıştır. Din ya da inançla birlikte sosyal hayatı da içine alan bunun yanında büyük ihtimalle ekonomik bir rolü de olan yapıların "Kamu Yapısı”, “Kolektif Yapı" veya "Özel Anıtsal Yapılar” gibi tanımlayıcı terimlerle ele alınması gerekmektedir. "Kamu Yapısı” terimi aslında Neolitik Çağ gibi yazısız ve birebir ilişkilendirilebilecek kanıtlardan yoksun olan dönemin bu tür anıtsal yapıları için kullanılması daha uygundur. 
Bu çalışmanın amacı hem Yukarı Dicle Bölgesi'nde hem de çevresinde bulunan önemli merkezler ve bu merkezlerde ortaya çıkarılan anıtsal yapıların Boncuklu Tarla örnekleri ile özellikle de Doğu alanda ortaya çıkarılan "Kamu Yapısı (Stelli Yapı)" ile karşılaştırılmasıdır. Anıtsal yapılardan kasıt ise sosyal, ekonomik, kültürel ve dini organizasyonların merkezi konumundaki büyük ölçekli ve özel yapılarıdır. Yukarıda da değinildiği üzere "Kamu Yapıları" olarak ele alınan ve dönemlerini en iyi anlatan bu yapılar bulundukları yerleşimlerin odak noktası halindedirler. Yerleşim yerindeki konumları ile dikkat çeken, bazı merkezlerde farklılık göstermesine karşın konutlardan ayrı tutulan bu yapılar Boncuklu Tarla Kamu Yapısı "Stelli Yapı" üzerinden açıklanmaya çalışılmıştır. Bahsi geçen yapıların köy-mekan organizasyonundaki yerleri, farklılıkları ve benzerlikleri, bu yapıların değerlendirilmesi gibi konular açıklanmıştır.

\section{Boncuklu Tarla'nın Konumu}

Boncuklu Tarla, Ilısu Barajı kapağının 3 km güney-batısında (Kartal ve diğ., 2014; Kodaş, ve diğ. 2019: 3; Ökse ve diğ., 2010; Taşkıran ve Kartal, 2010), Dicle Nehri'nin yaklaşık 2 kilometre batısında ve Nevala Maherk çayının güneyinde bulunmaktadır $^{3}$ (Resim 1) (Kodaş, 2018; Kodaş, ve diğ. 2019: 3). Yerleşim yeri, llısu Barajı ve HES Projesi Etkileşim Alanında Kalan Kültür Varlıklarının Belgelenmesi ve Kurtarılmasına Yönelik Çalışmalar kapsamında yapılan yüzey araştırmalarında ilk kez 2008 yılında iki farklı ekip tarafından tespit edilmiş ve incelenmiştir. Prof. Dr. Tuba Ökse Ilısu Barajı Inş̧aat Sahası Yüzey Araştırması kapsamında Boncuklu Tarla'yı Çanak Çömleksiz Neolitik Dönemi temsil eden bir yerleşim yeri olarak nitelendirilmiştir4 (Kodaş, 2018: 7; Kodaş ve Erdoğan, 2019: 694; Ökse ve diğ., 2010: 334, 341). Prof. Dr. Harun Taşkıran ve Prof. Dr. Metin Kartal Ilısu Baraj Gövdesi Alanı Yüzey Araştırması kapsamında yaptıkları yüzey araştırması sırasında Boncuklu Tarla yerleşim yerinde prehistorik döneme ait buluntular tespit etmişlerdir5 (Kartal ve diğ., 2014; Taşkıran ve Kartal, 2010 : 239-41). Yerleşim yerinde 2012, 2017 ve $2019^{6}$ yılında yapılan arkeolojik çalışmalar ve C14 analizleri yerleşim yerinin Geç Epipaleolitik Dönem'den Geç PPNB 7 sonuna kadar 6 ayrı tabakaya sahip olduğu ve MÖ 11. ile 8. bin arasında aralıksız iskan edildiği tespit

3 Yerleşim yeri aynı zamanda Çanak-Çömleksiz Neolitik döneme ait Çemka Höyük yerleşiminin kuş uçuşu yaklaşık olarak 500 metre batısında bulunmaktadır.

4 Yerleşim yeri, Ilısu Barajı ve HES Projesi Etkileşim Alanında Kalan Kültür Varlıklarının Belgelenmesi ve Kurtarılmasına Yönelik Çalışmalar kapsamında ilk kez 2008 yılında Prof. Dr. Tuba Ökse Ilısu Barajı İnşaat Sahası Yüzey Araştırması kapsamında Çanak Çömleksiz Neolitik Dönem yerleşim yeri olarak tanımlanmıştır (Alan No 26) (Kodaş, 2018: 7; Kodaş ve Erdoğan: 2019: 694).

5 Prof. Dr. Harun Taşkıran ve Prof. Dr. Metin Kartal Ilısu Baraj Gövdesi Alanı Yüzey Araştırması kapsamında yaptıkları yüzey araştırması sırasında yerleşim yerinde Çanak Çömleksiz Neolitik Dönem'e tarihlenen obsidiyen ve çakmaktaşı parçaları toplamışlardır (Kodu T 64) (Kodaş, 2018: 8; Kodaş ve Erdoğan: 2019: 694).

6 2012, 2017 ve 2019 yılında Boncuklu Tarla'da gerçekleştirilen kurtarma kazıları Mardin Müze Müdürlüğü başkanlığında yürütülmüştür. Ayrıca 2017'den beri kazının bilimsel danışmanlığını Mardin Artuklu Üniversitesi Arkeoloji Bölümünden Doktora Öğretim Üyesi Ergül KODAŞ yürütmektedir.

7 PPN: Pre-Pottery Neolithic (Çanak-çömleksiz Neolitik). 
edilmiştir (Kodaş, 2018; Kodaş, 2019a; Kodaş ve Genç, 2019; Kodaş, ve diğ. 2019: 3). Şimdiki verilere bakılarak yerleşim yerinin Geç Epipaleolitik Dönem'den Geç PPNB'ye kadar neredeyse aralıksız iskan edilmesi Mardin bölgesi ve tarihi için Boncuklu Tarla ilk örnek olarak karşımıza çıkmaktadır. Bu özelliğinden dolayı Boncuklu Tarla kazıları Mardin'in tarihi ve arkeolojisi için de önemli bir yere sahiptir.

\section{Boncuklu Tarla Stratigrafisi ve Mimari Kalıntılar}

Son dönem verilere dayanılarak, 2012, 2017 ve 2019 yıllarında yapılan kazılarda elde edilen buluntu, bulgular ve tarihleme (C14) yöntemi sonucu yerleşim yerinde Epipaleolitik Dönem'den Geç PPNB'ye kadar 6 ayrı tabaka tespit edilmiştir. Boncuklu Tarla'daki tabakalanmaya bakıldığında: Tabaka 1: Geç PPNB; Tabaka 2: Orta PPNB; Tabaka 3: Erken PPNB; Tabaka 4: PPNA-PPNB geçiş evresi; Tabaka 5: PPNA; Tabaka 6: Epipaleolitik $^{8}$ (Kodaş, 2018: 8; Kodaş ve Erdoğan, 2019: 694; Kodaş, ve diğ. 2019: 3). Boncuklu Tarla üzerinde tarımsal faaliyetlerden dolayı üst tabakalarda oldukça aşınma olmuştur ve yapılan kazı ve sondajlar sonucunda yerleşim yerinde kültür dolgusunun yaklaşık olarak 2,5 metre kalınlığında olduğu saptanmıştır (Kodaş, 2018: 9; Kodaş ve Erdoğan, 2019: 695).

Genel olarak Boncukla Tarla mimarisine bakıldığında, Geç PPNB'ye ait tabakada yapılan kazılar sonucunda iki adet hücreli yapı saptanmış, iyi korunmuş olan yapıların uzunluğu 10 metre ve genişliği yaklaşık olarak 5,5 metredir (Kodaş, 2018: 9-10; Kodaş ve Erdoğan, 2019: 695). Orta PPNB'ye ait tabakada yapılan kazılar sonucunda bu dönemde ilk kez yapılan 'Terrazo Binası' ortaya çıkarılmıştır (Kodaş, 2018: 10; Kodaş ve Erdoğan, 2019: 695). Terrazo Binası yaklaşık 15x13 metre boyutlarında olup yapının içinde çatıyı taşıdığı düşünülen 4 ayrı dikme/stelin ise tarımsal faaliyetlerin vermiş olduğu tahribattan dolayı sadece yuvaları tespit edilebilmiştir (Kodaş, 2018: 10; Kodaş ve Erdoğan, 2019: 696). Yapılan kazılar sonucunda gündelik yaşam için kullanılan konutların Terrazo Binası'nın batısında, tarımsal ürünlerin saklanması veya korunması için yapılan siloların (depo) ise binanın doğusunda yapıldığı tespit edilmiştir (Kodaş, 2018: 11). Erken PPNB'ye ait mimari buluntular sadece yapılan sondajlar sonucunda tespit edilmiştir. Bu dönemin mimari özelliklerini yansıtacak bilgiler kısıtlı olmakla birlikte ancak yapılacak yeni kazılar sonucunda daha ayrıntılı bilgiler elde edilecektir (Kodaş, 2018: 12; Kodaş ve Erdoğan, 2019: 696). Boncuklu Tarla PPNA dönemi mimarisi ise şuan ki çalışmalarda tam olarak ortaya çıkarılamamış ancak alanın kuzeyindeki yamaç kısmında ele geçen buluntularla desteklenmiştir. Aynı şekilde Doğu Alanında da elde edilen son verilerle bu dönemin yapıları

8 Yerleşim için atıfta bulunulan tüm dönem ve tarihler kazıda elde edilen buluntu ve bilgilerin değerlendirilmesi ve benzerleri ile karşılaştırılması sonucu varılan yaklaşık sonuçlardır. Bu bağlamda yerleşmenin farklı tabaka ve kontekstlerinden alınan analiz örnekleri “TÜBITAK Marmara Araştırma Merkezi” laboratuarına gönderilmiş ve C14 yaşlandırma yöntemi (Radyokarbon) uygulanmıştır ve 3 örnekte yaşlandırma yapılabilmiştir. 
belirlenmeye başlanmıştır. Boncuklu Tarla'nın Epi-Paleolitik dönemine ait en alt tabakaya ait mimari ise yine kuzey sınırda, yamaçta ortaya çıkarılan yuvarlak "Payeli Kamu Yapısıdır".

\section{Küçük Buluntular}

Boncuklu Tarla'da ele geçen küçük buluntular arasında boncuklar öne çıkmakla birlikte bilezikler, kulak tıkaçları/küpeler, figürlü taş objeler ve kemik plakalar küçük buluntular için örnek buluntular arasında yer almaktadır (Kodaş, 2018: 15; Kodaş ve Erdoğan, 2019: 700). Yerleşim yerine ismini veren boncukların hammaddeleri serpantin, kireçtaşı, klorit, kumtaşı, kemik, obsidiyen, malakit ve değişik çay taşlarının yoğun olarak kullanıldığı görülmektedir (Resim 2) (Kodaş, 2018: 15; Kodaş ve Erdoğan, 2019: 700). Figürlü boncuklara baktığımızda çoğunlukla hayvan motiflerinden oluştuğu ve özellikle boğa başı, geyik, leopar, yaban keçisi başı, yılan, kuş ve akrep biçimlidirler (Resim 3) (Kodaş, 2018: 15; Kodaş ve Erdoğan, 2019: 700). Özellikle Boncuklu Tarla'da boncuk yapımında kullanılan hammaddeler arasında bakırtaşı (malakit) ve bakırın kullanılmış olması daha önceden Çayönü, Aşıklı Höyük, Tell Halula gibi yerleşimlerden de bilinen örneklerde olduğu gibi bizlere madencilik tarihi hakkında yeni bilgiler vermektedir (Kodaş, 2018: 16; Kodaş ve Erdoğan, 2019: 700-701). Yapılan kazılarda figüratif yönleri ile öne çıkan Boncuklu Tarla'daki buluntuları içerisinde insan ve hayvan figürinleri bulunmamıştır (Kodaş, 2018: 16; Kodaş ve Erdoğan, 2019: 700).

Boncuklar haricinde farklı taşlardan yapılmış (kireçtaşı, kumtaşı, mermer, obsidyen, vb.) kulak tıkaçları (stone plugs) veya küpeler, sayma taşları (token veya jeton) yapılan kazılarda bulunmuştur (Kodaş, 2018: 17; Kodaş ve Erdoğan, 2019: 700-701). Kemik objelere bakıldığında kabartmalı veya çizgi bezemeli kemik objelerin sayıları az olmakla birlikte farklı formda ve teknikte üretilmiştir (Kodaş, 2018: 17-18). Kemik objeler arasında kakma tekniği ile yapılmış oldukça nadir olan ve üzerinde iki örümcek motifli buluntuya bakıldığında, söz konusu motifler kemik plak üzerine kazılmış olan iki örümcek motifinin (kakma yuvalarının) yeşilimsi taşların (bazıları malahit?) yapıştırılmasıyla yapılmıştır (Resim 4) (Kodaş, 2018: 18). Boncuklu Tarla'da az da olsa üzerinde geometrik bezemelerin bulunduğu ve yapımında daha çok siyah çay taşları, klorit ve sabuntaşının kullanıldığı taş objeler yapılan kazılarda yerleşim yerinde bulunan küçük buluntulara örnektir (Kodaş, 2018: 18). Ayrıca boyutları 5-8 cm yarıçapında değişen ve mermerden yapılmış yaklaşık olarak 10 tane bilezik yapılan kazılar sonucunda bulunmuştur (Kodaş, 2018: 18). 


\section{Yontmataş Buluntular}

Boncuklu Tarla'da yontmataş alet üretiminde obsidyenden yapılan aletler bulunmuşsa da alet üretiminde hammadde olarak yoğun olarak çakmaktaşından faydalanmıştır (Kodaş, 2018: 13; Kodaş ve Erdoğan, 2019: 698). Özellikle kazıdan çıkan toprakların kazı alanında yüzdürme yoluyla yıkama ve eleme yöntemleri sayesinde mikrolit alet ve mikrolit çekirdekleri bulunmuştur (Kodaş, 2018: 14). Bu küçük buluntular sayesinde dönemim alet üretimi hakkında önemli bilgiler elde edilmiştir (Kodaş, 2018: 14).

\section{Mezarlar}

2017 ve 2019 yılı kazı çalışmalarında kazılan 70 mezardan 130 bireye ait kalıntı açığa çıkarılmıştır (Resim 5) (Kodaş, 2018: 14; Kodaş ve Erdoğan, 2019: 699). Erkek, kadın ve çocuk bireylerin gömüldüğü mezarların tamamı mekân içi gömüt niteliğindedir (Kodaş, 2018: 14; Kodaş ve Erdoğan, 2019: 699). Birincil gömütlere ait olan mezarların yanı sıra 3 adet ikincil gömü ve hatta kafatası kültüne ait olabilecek 7 ayrı mezarda açığa çıkartılan 9 bireye ait kafatası bulunmaktadır (Kodaş, 2018: 14; Kodaş ve Erdoğan, 2019: 699). Ayrıca 9 adet ikili bireyin, 5 adet üçlü bireyin, 1 adet dörtlü bireyin, 1 adet altılı bireyin, 2 adet yedili bireyin ve 1 adet de onbir bireyin bulunduğu çoklu mezarlar yapılan kazılar sonucunda ortaya çıkarılmıştır (Kodaş, 2018: 14-15). Bu buluntular bizlere Çanakçömleksiz Neolitik dönem ölü gömme gelenekleri hakkında önemli veriler vermektedir.

\section{Boncuklu Tarla Doğu Alanı “Kamu Yapısı” ve Doğu Alanı Genel Mimarisi}

Boncuklu Tarla Doğu Alanı'nda açığa çıkarılan mimari kalıntılar toplamda 3 ayrı yapı katı (4a, 4b ve 5. tabaka) üzerinden ele alınmıştır. Söz konusu kalıntılar bakıldığında, 4a ve 5 . tabakaya ait mimari kalıntılar daha az sayıdaki örnekle temsil edilmekle birlikte, inşa tarzları ve planları bakımından kendi içerisinde önemli farklılıklar sergilemektedirler (Resim 6) (Kodaş, 2018; Kodaş, 2019a). Boncuklu Tarla yerleşiminde genel olarak Tabaka 4 PPNA-PPNB Geçiş Dönemine aittir ve Tabaka 5 ise PPNA'ya aittir (Kodaş, 2018: 12; Kodaş ve Erdoğan, 2019: 696). Kısaca bu tabakaların mimarisine bakıldığında;

\section{4a Tabaka Mimarisi}

Bu tabaka mimarisi ızgara planlı bir yapı (Str. 5) ve yine ızgara planlı başka bir yapıya ait olduğu düşünülen bir kaç duvar kalıntısı ile temsil edilmektedir (Resim 6). Tarımsal aktivitelerden dolayı kötü korunmuş olan söz konusu yapı (Str. 5) yaklaşık 7 metre uzunluğunda ve 5 metre genişliğindedir. Taş temelli olan yapıya bakıldığında tahribattan dolayı yapının duvarlarına ait herhangi bir veriye 
ulaşılmamıştır. Fakat söz konusu yapının tabanı sıkıştırılmış toprak ile yapılmıştır. Binaya detaylı bakıldığında doğu bölümünde $5 \times 4$ metre boyutlarında olan bir mekanın var olduğu ve bu alanda ızgaraların olmadığı, fakat binanın batı bölümünde ise kötü korunmuş olmakla birlikte ızgaralar olduğu görülmektedir. Söz konusu bina aynı zamanda 4b tabakasına ait yuvarlak planlı bir yapının üzerinde bulunmaktadır ve $4 \mathrm{~b}$ tabakasına ait Stelli Bina'nın (Str. 1) hemen kuzey batısında yer almaktadır. Fakat Stelli Bina'nın 4a tabakasında kullanıldığına dair herhangi bir bilgi şuan için mevcut değildir. Çayönü yerleşiminde Izgara Planlı yapılar evresinin mimari kalıntıları oldukça düzgün iken (Erim-Özdoğan, 1994; Erim-Özdoğan, 2007) Boncuklu Tarla Doğu Alanı örneklerinde bu görülmemektedir. Oldukça basit bir şekilde yapılmıș olan yapılar ihtimalle yüzeye yakın olmalarından dolayı tahrip olmuşlardır. Bu tip yapıların varlığı Çayönü dışında PPNA-PPNB merkezlerinde pek bilinmemektedir.

\section{4b Tabaka Mimarisi}

Bu tabakaya ait mimari kalıntılar sadece höyüğün doğu alanında açılan J20-21 ve K20-21 açmalarında tespit edilmiştir (Resim 6). Bu dönemin konut mimarisi 8-10 x 2-5 metre boyutlarındaki köşeleri yuvarlatılmış yapılarla (Str. 2, 3, 7) ve aynı alanda açığa çıkarılan yuvarlak planlı yapılarla temsil edilmektedir (Str. 4 ve 6). Bu binaların etrafında yapıların kapı girişlerinin karşısına denk gelen alanlarda silo tabanları tespit edilmiştir. Alanda açığa çıkarılan konutların tamamı tek odalıdır ve köşeli planl, yere gömülü olarak inşa edilmiş olan 'Kamu Binası'nın etrafında bulunmaktadır (Str. 1; Resim 6) (Kodaş, 2018: 12; Kodaş ve Erdoğan, 2019: 696-697).

Bu döneme ait konutların ortasında bulunan söz konusu 'Kamu Binası (Stelli Bina)' ise yaklaşık 8,50x8,30 metre boyutlarındadır (Resim 7) (Kodaş, 2018: 12). Yapılan kazılar sonucunda binanın yaklaşık olarak 2 metre bir derinliğe sahip çukur içerisine gömülü olarak inşa edilmiş olduğu, fakat etrafında bulunan evlerin ise yüzeyden $20-25 \mathrm{~cm}$ derinliğe sahip taş temellere sahip oldukları tespit edilmiştir (Kodaş, 2018: 12). Bahsi geçen PPNA-PPNB geçiş dönemi de dahil olmak üzere bölgede Çanak-Çömleksiz Neolitik Çağ yerleşimlerinde ortaya çıkarılan tüm "Kamu Yapıları" tam ya da yarı gömülü şekildedir. Binanın duvarları yassı doğal taşlar ve çamur harç ile inşa edilmiştir. Binanın merkezinde simetrik bir şekilde yerleştirilmiş olan 4 adet düz taş stel bulunmaktadır. Yaklaşık 1,50 cm yükseklikte olan söz konusu steller Yukarı Dicle Havzası'na özgü olan ve daha önceden Çayönü, Güsir Höyük ve Hasankeyf Höyük'te de bilinen sade ve düz bir form sergilemektedirler (Erim-Özdoğan, 2011; Karul, 2011; Kodaş, 2015; Miyake ve diğ., 2012; Özdoğan, 2018) ve Şanlıurfa Bölgesi'nde bulunan yerleşimlerde olduğu gibi T biçimli bir form sergilememektedirler (Hauptmann, 2011; Schmidt, 2011). Söz konusu binayı özel kılan durumlardan bir diğeri ise binanın kuzey-doğu duvarında 2 ve güney-batı duvarında ise 3 adet payanda tipinde niş bulunmasıdır. Kamu yapısı olarak ele alınan Stelli Yapı dikdörtgen bir form vermektedir. Binanın 
kuzeybatı duvarı üzerinde herhangi bir yenileme izi yokken binanın güneybatı uzun duvarı ve güneydoğu kısa duvarı üzerinde yenileme izlerine rastlanmıştır. Güneybatı duvarı üzerindeki yenileme işlemi aslında iki farklı duvarın varlığına işaret etmektedir. Büyük ihtimalle bu yenileme işlemi sırasında eski duvar eğimden de kaynaklı olarak içe doğru çökme yapmış, ikinci duvar da buna istinaden oturtulmuş ve yine bu duvara destek amaçlı çıkıntıları/payeleri oturtulmuştur. Payelerle birlikte, eski ve yeni duvarın olduğu kısımda ihtimalle tahrip olmuş kısa bir seki/bank ya da platforma yer verilmiştir. Bu yeni duvarın kuzey ucunda çok küçük ölçülerde pencere gibi bırakılmış oldukça derin bir niş açığa çıkarılmıştır. Nişin içinin sıvalı olması da oldukça ilginç bir uygulama gibi görünmektedir. Niş içinde herhangi bir buluntu ele geçmemiştir. Güneybatı duvarının kalınlaştırılması ve sağlamlaştırılması için yapılan uygulamalar aynı şekilde güneydoğu duvarında da görülmektedir. Ancak bu duvarda ilginç olarak farklı taşlar kullanılmış ve kalınlaştırma yapılmamıştır. Aksine diğer üç duvara göre oldukça ince görünen bu duvarın neden böyle bırakıldığı anlaşılmamaktadır. Binanın gömülü olduğu düşünüldüğünde çevresindeki toprağın baskısı da üzerine geldiğinde yıkılması muhtemel olan güneydoğu duvarının sadece üst sıra birkaç taşının değişmesi ilginçtir.

Kamu Yapısı içerisinden oldukça fazla dolgu toprak çıkarılmış, yapının içinde çakmaktaşı ve obsidyen alet ve alet parçaları, kemik aletler, taş aletler ve oldukça iri düzensiz bağımsız kayalar da bulunmuştur. Yapının dolgu toprağının ise yanık malzeme ve hayvan kemikleri ile dolu olması aslında yapının terk edildikten sonra çöp atım alanı olarak kullanıldığını düşündürmüş ancak çalışmalar ilerledikçe buranın bilinçli olarak doldurulduğu fark edilmiştir. Birçok yerleşimde açığa çıkarılan anıtsal yapılarda bu uygulamanın varlığından bahsedilmiş ve kullanımdan düşen ya da halkın o yerleşimi terk etmeden önce binayı bilinçli olarak doldurulduğu veya yapının yakıldığı görülmüştür (Özdöl, 2011, 195). Bu uygulamanın Boncuklu Tarla Doğu Alanı Stelli Yapısı için uygulanıp uygulanmadığı henüz kesin değildir. Değerlendirmeler için gerekli analizlik malzemeler toplanmış ve gerekli yerlere ulaştırılmıştır. Stelli Yapı biçim olarak her ne kadar Nevali Çori ve Göbekli Tepe (Aslan Payeli Yapı) Kamu Yapılarına benzese de dönemsel farklııılar ve stel farklılıkları bulunmaktadır. Her iki merkezde ortaya çıkarılan yapılar PPNB/ÇÇNB dönemi örneklerini oluşturmaktadır. Boncuklu Tarla Stelli Yapı ise PPNA-PPNB Geçiş Evresine ait bir yapıdır. Ayraca Boncuklu Tarla'daki yapı, Kuzey Suriye topraklarında bulunan Mureybet (Stordeur ve Ibáñez, 2008), Jerf El Ahmar (Stordeur, 2014) ve Djade El Mughara (Coqueugniot, 1994; 1998; 2011) "Kamu Yapıları" ile dönemsel olarak aynı olsalar da biçim ve iç düzenleme yönünden oldukça farklılık göstermektedirler.

\section{Tabaka Mimarisi}

PPNA tabakasına ait mimari kalıntılar çok kısıtlı bir alanda tespit edilmiştir. J21 açmasında iki adet yuvarlak planlı yapı ortaya çıkarılmıştır (Str. 12-13; Resim 6). 
J21 açmasındaki bu yuvarlak planlı yapılar yaklaşık 1,5-2 metre çapındadır ve konut olmaktan çok silo oldukları düşünülmektedir (Kodaş, 2018: 13; Kodaş ve Erdoğan, 2019: 697). Bu yapıların benzerleri Hallan Çemi yerleşiminde ortaya çıkarılmış, çoğunlukla "C" tipinde olan konutlarına benzer özellikler sergilemelerinin yanında tam yuvarlak örnekleri de bulunmaktadır (Rosenberg, 2007: 2). Özellikle taş döşeme tabanları olan yapıların ya da siloların Boncuklu Tarla yerleşiminde ayırımları henüz kesinleşmemiştir.

\section{Köy-Mekan Organizasyonları}

Boncuklu Tarla Doğu Alanı köy-mekan organizasyonuna genel olarak bakıldığında sadece $4 \mathrm{~b}$ tabakasının konu hakkında bilgi verdiği gözlemlenmektedir. Söz konusu döneme ait mimari kalıntılara detaylı bakıldığında ise Kamu Binası'nın (Stelli Bina) merkezde olduğu ve bu binanın etrafında da yuvarlak veya yarı yuvarlak formda olan konutların bulunduğu görülmektedir. Genellikle birbirinden bağımsız olarak inşa edilen konutların iki tanesinin Stelli Bina'nın doğu ve batı yönünde inşa edildikleri ve söz konusu Stelli Bina ile ortak duvarlarının olduğu gözlemlenmektedir. Stelli Bina'nın etrafında bulunan konutlara bakıldığında ise tüm konutların içerisinde mezarların var olduğu ve günlük aktivitelere işaret eden öğütme taşları, havanelleri ve ocakların olduğu görülmektedir. Buna karşın Kamu Binası'nın (Stelli Bina) içerisinde söz konusu buluntular ele geçmemiştir. Ancak yapı içindeki dolgu toprakta birçok buluntu olmasına karşın muhtemelen doldurma işlemi sırasında atıldıkları düşünüldüğünden yapı ile ilişkilendirilmemişlerdir. Kuşkusuz bir Kamu Binası olan Stelli Bina'ya ek olarak konutlar arasında ortak kullanım alanı olan açık alanların ve bu alanlarda da yuvarlak planlı silo tabanlarının olduğu gözlemlenmektedir (Str. 8-11). Bu tabakaya ait köy-mekan organizasyonlarına toplu olarak bakıldığında ise Boncuklu Tarla'da bu döneme ait 4 ayrı alanın olduğu görülmektedir: Kamu Binası, konutlar, silolar ve binalar arası geçişi sağlayan ortak açık alanlar. Ortak açık alanlar Jerf El Ahmar (Stordeur, 2014) ve Tell Abr 3 (Yartah, 2013) gibi Kuzey Suriye Bölgesi merkezlerinde genellikle bulunur. Nevali Çori'de ise Kamu Yapıları kuzey alanda yerleştirilmiş, konutlarla kamu yapıları arasında fazla olmasa da bir genişlik bulunmaktadır (Hauptmann, 2007). Çayönü'nde ise anıtsal bir ortak kullanım alanı mevcuttur (Erim-Özdoğan, 2007). Boncuklu Tarla Kamu Yapısı ile iniltili olduğu düşünülen Str 2 yapısı aslında bu anıtsal yapıya koşut olarak yapılmış gibi görünmektedir. Sadece bir ek olarak görünen yapı aslında oldukça işlevli ve önemli bir yapıdır. Boncuklu Tarla Doğu Alanı "Stelli Yapısı" diğer aynı yerleşimde bulunana kamu yapıları olan Terazzolu Yapı ve Payeli Yapı gibi yerleşimin odak noktasını oluşturmaktadır. Aynı şekilde Yukarı Dicle Bölgesi'nde Güsir Höyük (Karul, 2011), Hasankeyf Höyük (Miyake ve diğ., 2012; Miyake, 2013), Çayönü (Erim-Özdoğan, 1994; Erim-Özdoğan, 2007), Yukarı Suriye Bölgesi'nde Mureybet (Stordeur ve Ibáñez, 2008), Tell Abr 3 (Yartah, 2013), Jerf El Ahmar (Stordeur, 2014), Djade El Mungara (Coqueugniot, 
1994; 1998; 2011), Cezire Bölgesi'nde Qermez Dere (Watkins vd., 1989; Watkins vd., 1995) ve Nemrik 9 (Kozlowski ve Kempisty, 1990) gibi merkezlerde bu organizasyon görülmektedir. Göbekli Tepe'de ise PPNA/ÇÇNA dönemine tarihlendirilen yuvarlak, "T" payeli yapıların bulunduğu tabakada sivil yapıya ait veriler henüz bulunmadığından şuan için böyle bir organizasyondan bahsetmek mümkün değildir. Bunun yanında Göbekli Tepe PPNB/ÇÇNB tarihlendirilen "Aslan Payeli Yapı" aslında böyle bir organizasyonu göstermektedir ancak kazıcısı tarafından yapının çevresindeki ufak yapılarda birer "Kült Yapısı" olarak kabul edildiğinden “Aslan Payeli Yapı”nın etrafında konut ya da diğer işlevli yapıların varlığından bahsetmek mümkün değildir (Schmidt, 2007).

\section{Sonuç}

Yukarı Dicle Havzası'nda son yıllarda yapılan arkeolojik çalışmalar hem bölgenin Neolitik kültürleri üzerine yeni bilgilerin elde edilmesini hem de Dicle Havzası ile çevre bölgeler arasında karşılaştırmaların yapılmasına önemli katkılar sağlamıştır. Bu bağlamda dönemin Kamu Binaları ve köy-mekan organizasyonları üzerine yeni bilgiler elde edilmiştir. Boncuklu Tarla Doğu Alanı'nda açığa çıkarılan mimari öğeler ise bu bağlamda Yukarı Dicle Havzası'nda hem Çanak-Çömleksiz Neolitik (PPN) dönem mimarisinin kronolojik gelişimi hem de dönemin köymekan organizasyonları ve kamu binası mimarisi hakkında bölgesel ve bölgeler arası ilişkiler bağlamında önemli bilgiler vermektedir. Kendine has bir planı ve iç düzeni olan söz konusu Kamu Binası'nın etrafında organize olmuş olan konutlar, silolar ve binalar arası geçişi sağlayan ortak açık alanlar yerleşim yerinin bir planlama ile inşa edildiğini düșündürmektedir. Bunun yanı sıra Kamu Binası'nın bir çukur içerisinde inşa edilmiş olması ortak bir iş gücü ve organizasyona işaret etmektedir. Boncuklu Tarla Doğu Alanının, 4b tabakası, mimarisi bu bağlamda benzer bir sistem ile inşa edilmiş olan Çayönü (Erim-Özdoğan, 1994; ErimÖzdoğan, 2007), Nevali Çori, Göbekli Tepe, Jerf el-Ahmar gibi yerleşim yerleri ile benzer özellikler sergilemektedir (Kodaş, 2015; Stordeur, 2014;). Fakat kamu binasının planı ve içerisinde bulunan sade taş steller ve 4a tabakasına ait ızgara planlı konut daha çok Yukarı Dicle Bölgesi mimari gelenekleri ile bağlantılıdır (Kodaş, 2019b; Özdoğan, 2018). Boncuklu Tarla Doğu Alanı Kamu Yapısı mimari unsurları, köy-mekan uygulamaları ile de farklı bir yere sahiptir. Farklı tipte konutların ortasında bulunan yapı, merkezi bir sistem ağının içindeymiş gibi görünmektedir. Aynı durum daha geç dönem (Orta PPNB) yapısı olan Boncuklu Tarla'da açığa çıkarılan Terazzo yapısında da görülmektedir. Kompleks bir yapı özelliğine sahip olan Terazzo Yapısı çevresindeki konutlara bağlı olarak, doğusunda depo/silo açık alanlara ve kendisine ek olarak yapılmış işliklere sahiptir. Ve insanların yaşadığı mekânlar Terrazo yapısının batısında yer almaktadır. Boncuklu Tarla'daki merkezi bir sisteme yönelik yapılan özel yapıların aslında bölgede daha erken dönemlere ait olan Güsir ve Hasankeyf Höyük sistemine benzemektedir (Karul, 2011; Karul, 2013; Miyake ve diğ., 2012; Miyake, 
2013). Aynı şekilde Jerf El Ahmar EA30 ve EA53 yapıları yine orta kısımda yer almış ve etrafı boş bırakılarak ortak alan olușturulmuştur (Stordeur, 2014). Fakat, Boncuklu Tarla Terazzo Yapısından daha erken olan Stelli Yapı'da bu kadar belirgin bir ayrıma sahip değildir. Biçimsel olarak Nevali Çori (Hauptmann, 1993; Hauptmann, 2007; Hauptmann, 2011) yapısına oldukça benzeyen Stelli Yapı yerleşim organizasyonu ve dönemi bakımından ayrılmaktadır. Boncuklu Tarla Doğu Alanı sadece Kamu Alanı (Stelli Alan) ile belirgin bir ayarıma sahip değildir. $\mathrm{Bu}$ alanda ortaya çıkarılan karma konutlarda da değişkenlik söz konusudur. Köşeleri yuvarlatılmış yapılar PPNA-PPNB geçiş dönemine ait yapılardan oluşmaktadır. Özellikle Str 6 yapısı yarım ay şeklindeki (C) duvar örgüsüyle Hallan Çemi (Rosenberg, 1995; Rosenberg, 1998; Rosenberg, 2007; Rosenberg, 2011; Rosenberg ve Davis, 1992) Erken PPNA örneklerini ile benzer özellikler yansıtmaktadır. Hallan Çemi basit konutları olarak geçen bu yapılar erken konut örneklerinden sayılmaktadır. Duvar örgüsü ve diğer benzerliklerle Boncuklu Tarla Doğu Alanı örneği olan Str6 yapısı ise ihtimalle zamansal bir ayrılığa bağlı olarak farklılık göstermektedir. Izgara Planlı yapılar ise Çayönü yerleşiminden bilinmektedir (Erim-Özdoğan, 1994; Erim-Özdoğan, 2007). Boncuklu Tarla Yapı örneklerinin biraz zayıf kaldığı bu tip mimari yapılar yüzeye oldukça yakın olduklarından tahribata maruz kalmışlardır.

Boncuklu Tarla Doğu Alanında ortaya çıkarılan mimari unsurlara ek olarak silo/depo yapıları da ilgi çekicidir. Aslında Boncuklu Tarla'da birçok silo alanı ortaya çıkarılmıştır. Bunlar genellikle terazzo taban ile oluşturulan yuvarlak yapılardan meydana gelirken, bazı örneklerde taş tabanlılar da ele geçmiştir. Bu taş tabanlı silo yapıları genellikle sıkıştırılmış toprak ile tamamlanmış gibi durmaktadır. Doğu alanında ortaya çıkarılan silo yapılarında nehir taşlarıyla oluşturulmuş zemin doğrudan toprak içine hafif ovallik yapılarak yerleștirilmiştir. Ancak taban yüzeyinin işlemini gösteren herhangi bir olguya rastlanmamıştır. Hasankeyf (Miyake ve diğ., 2012; Miyake, 2013) ve Güsir Höyük (Karul, 2011) örneklerinde de görünen bu tip silolar ihtimalle sert toprakla kaplı olmalıdırlar. Boncuklu Tarla da dahil olmak üzere Güsir, Hasankeyf merkezleri kısacası Yukarı Dicle Bölgesi merkezleri daha çok Kuzey Suriye Neolitik merkezlerine benzemektedir. Yukarı Suriye bölgesi merkezlerinde de oldukça fazla taş döşeme tabanlı depo yapıları ortaya çıkarılmış, buluntular ve mimari özelliklerle birlikte birebir olmasa da yakın bir benzerlik içindedirler.

Boncuklu Tarla Doğu Alanında mimari unsurlar dışında Kamu Binası (Stelli Yapı) içinden mezar buluntuları hiç ele geçmemiş ancak çevresinde bulunan konutlardan toplamda 16 mezar ve 20 birey ortaya çıkarılmıştır. Aynı şekilde Stelli Yapı'nın çevresinden oldukça fazla işlenmiş taş aletler, dilgi ve dilgicikler, konutlarda havanelleri ve vurgaçlar ele geçmiştir. Stelli Yapı içinden ise ilişkili buluntu olmamasına karşın içinden çıkarılan dolgu toprakta oldukça fazla hayvan kemikleri, kırık aletler ve yongalar ele geçmiştir. 
Yukarıda da bahsi geçen merkezlerde ortaya çıkarılan yapıların ve Boncuklu Tarla anıtsal yapılarının tarihi ve kültürel önemlerinin yanında geçmişi anlamakta bizlere yadsınamaz bilgiler sunmaktadırlar. Tarihi, kültürel bir obje olmalarının yanında kendi dönemlerinin uygulamaları, sosyal hayatları ve bunlar gibi birçok saklı kalmış sırları açığa çıkarmaktadırlar. Bu sebeple bahsi geçen yapıların tek konuya (Tapınak, Din) cevap olmaları düşünülmemeli, birçok konuyla (Sosyal, Ekonomik, Kültürel ve Dini) birlikte ele alınmalıdırlar. Bu çalışmada ele alınan Boncuklu Tarla anıtsal kamu yapıları da incelendiğinde birçok yenilik ve farklılık görülmektedir. Bunlardan en önemlisi kamu yapısı/yapılarının o günkü hayat koşullarında merkezi bir öneminin oluşu ve dönemin dinamiğini yönlendirmeleriydi. Bu sebeple bu tür yapıların sadece tapınma için kullanıla gelen bir tapınak yapısından çok halkın ortak kullanımı, ortak sorunların ve kararlarının alındığı, gerekli aktivitelerin yapıldığı bir alan olarak görülmektedir. Son Kamu Yapısı ise Epipaleolitik Çağ’a tarihlendirilen ve kesinlikle çok farklı bir yeri ve önemi olan payeli yuvarlak yapıdır. Henüz yerleşik hayata geçmemiş insanların bu denli özel bir yapı yapması dikkate şayandır. Boncuklu Tarla'da yapılacak ilerideki çalışmalar bu yapının etrafında yapılacak ve ilk yerleşimin izleri aranacaktır.

\section{Kaynakça}

Aurenche, O. ve Kozlowski, S.K. (2000). La Naissance Du Néolithique Au Proche Orient. Paris: Editions Errance.

Coqueugniot, E. (1994). 'L'indutrie Lithique de Dja'de El Mughara et le Debut du PPNB sur L'Euphrate Syrien (Sondages 1991 et 1992).' H.G. Gebel et K. S. Kozlowski (Eds.). Neolithic Chipped Stone Indutries of the Fertile Crescent and Their Contemporaries in Adjacent Region. Studies in Early Near Eastern Production, Subsistence and Environment 2 içinde (ss. 313-330). Berlin.

Coqueugniot, E. (1998). "Dja'de El Mughara (Moyen-Euphrate), Un Village Néolithique Dans Son Environnement Naturel À La Veille De La Domestication." Espace Naturel, Espace Habité En Syrie Du Nord (10e - 2e Millénaires Av. J.-C.)/Natural Space, Inhabited Space In Northern Syria (10th 2nd Millennium B.C.). Actes Du Colloque Tenu À I'Université Laval (Québec) Du 5 Au 7 Mai 1997. Lyon: Maison De I'Orient Et De La Méditerranée Jean Pouilloux, 109-114.

Coqueugniot, E. (2011). “Des Peintures Dans Un Bâtiment Communautaire Du Néolithique Précéramique (Vers 9000 Av. J.-C.) À Dja'de (Syrie) : Nature, Insertion Dans L'architecture Et Tentative D'interprétation.” PAPERS, XXIV Valcamonica Symposium 2011, 151-156.

Erim-Özdoğan, A. (1994). “Çayönü Yerleşmesinin Çanak-Çömleksiz Neolitikteki Yeri” (Yayımlanmamış Doktora Tezi). İstanbul: İstanbul Üniversitesi Sosyal Bilimler Enstitüsü. 
Erim-Özdoğan, A. (2007). “Çayönü.” Anadolu'da Uygarlığın Doğușu ve Avrupa'ya Yayılımı, Türkiye’de Neolitik Dönem: Yeni Kazılar-Yeni Bulgular, İstanbul, 57-97. Erim-Özdoğan, A. (2011). 'Çayönü.' M. Özdogan, N. Basgelen, and P. Kuniholm (Eds.). The Neolithic in Turkey 1 içinde (ss.185-269). Istanbul: Archaeology and Art Publications.

Hauptmann, H. (1993). 'Ein Kultgebaude in Nevali Çori.' M. Frangipane vd. (Eds.). Between the Rivers and Over the Mountain içinde (ss. 38-69). Archaelogica Anatolica e Mezopotamica, Alba Plamieri Dedicata.

Hauptmann, H. (2007). 'Nevali Çori ve Urfa Bölgesi'nde Neolitik Dönem.' M. Özdoğan, ve N. Başgelen (Eds.). Türkiye'de Neolitik Dönem içinde (ss.131164). İstanbul: Arkeoloji ve Sanat Yayınları.

Hauptmann, H. (2011). 'The Urfa Region.' M. Özdogan, N. Basgelen, and P. Kuniholm (Eds.). Neolithic in Turkey Volume 2 içinde (ss.85-138). İstanbul: Archaeology and Art Publications.

Kartal, M. Taşkıran, H., Bulut, K., ve Dinç, O. (2014). "Yontmataş Bulgular Işığında Yukarı Dicle Havzası'nda Yeni Bir Neolitik Yerleşim: Boncuklu Tarla." Ankara Üniversitesi Dil-Tarih Coğrafya Fakültesi Dergisi 54, 489500.

Karul, N. (2011). 'Gusir Höyük.' M. Özdoğan, N. Başgelen, ve P. Kuniholm (Eds.). Neolithic in Turkey Volume 1 içinde (ss. 1-19). İstanbul: Archaeology and Art Publications.

Karul, N. (2013). "Güsir Höyük." Eski Dünya'nın Illk Köyleri, Yerleșik Avcılar, Atlas.

Kodaş, E. (2013). “Jerf el-Ahmar EA 30 Binası ve Yakındoğu'da PPPNA-PPNB'ye Geçiş Dönemine ait Kamu Binaları.” Tüba-ar, 16(1), 9-19.

Kodaş, E. (2015) “Le Bâtiment DE de Çayönü: un bâtiment au coffrage?” NeoLithic, 2015(1), 42-52.

Kodaş, E. (2018). "Yukarı Dicle'de Yeni Bir Çanak Çömleksiz Neolitik Yerleşim Yeri: Boncuklu Tarla Kazıları ve ilk Gözlemler." Arkeoloji ve Sanat Dergisi 158, 7- 20.

Kodaş, E. (2019 a). "Un nouveau site du Néolithique précéramique dans la vallée du Haut Tigre : Résultats préliminaires de Boncuklu Tarla." NeoLithics, 19(1), 3-15.

Kodaş, E. (2019b). “Kuzey Mezopotamya'da PPNA ve PPNA-PPNB Geçiş Dönemi'ne Tarihlenen 'Sembolik Objelerin' Bölgesel Dağılımı Üzerine Bazı Gözlemler. Kültürel Çeşitlilik ve Yorumlanması." Arkeoloji ve Sanat Dergisi, 161,1-22.

Kodaş, E. Genç, B. Labedan-Kodaş, C., İpek, B., Erdoğan, N. (2019). "Boncuklu Tarla Çanak-Çömleksiz Neolitik Dönem'e Tarihlenen Bir Grup Figürlü Kemik Plak." Artuklu Insan ve Toplum Dergisi, 4(1), 1-6.

Kodaş, E. ve Erdoğan, N. (2019). "Boncuklu Tarla 2017 Yılı Kazıları." 40. Kazı Sonuçları Toplantısı I, 693-710.

Kodaş, E. ve Genç, B. (2019). "Çemka Höyük: Yukarı Dicle Havzasında Bulunan Yeni Bir ÇÇNA ve Geç Epipaleolitik Dönem Yerleşim Yeri." Anadolu/Anatolia 45, 211-221. 
Kozlowski, S.K ve Kempisty, A., (1990). "Architecture of the Pre-Pottery Neolithic

Settlement in Nemrik, Iraq." World Archaeology, Vol. 21, No. 3, Architectural Innovation, 348-362.

Miyake, Y. (2013). “HasanKeyf Höyük”. Atlas, 96.

Miyake, Y. Maeda, O., Tanno K., Hongo H., ve Gündem C. Y. (2012) “New

Excavations at Hasankeyf Höyük: A $10^{\text {th }}$ Millennium Cal. BC Site on the

Upper Tigris, Southeast Anatolia." Neo-Lithic 1/12, 3-8.

Ökse, T., Görmüş, A. ve Atay, E. (2010). "Ilısu Barajı İnşaat Sahası 2008 Yüzey Araştırması." 27. Araştırma Sonuçları Toplantısı (I), 333-349.

Özdoğan, M. (2018). "Humanization of Building. The Neolithic Ritual of Burying the Sacred." Origini XLI(1), 7-24.

Özdöl, S. (2011). "Çanak Çömleksiz Neolitik Çağ'da Güneydoğu Anadolu'da Din ve Sosyal Yapı." Tarih Incelemeleri Dergisi, XXVI(1). 173-199.

Rosenberg, M. (2007). 'Hallan Çemi.' M. Özdoğan, ve N. Başgelen (Eds.),

Anadolu'da Uygarlığın Doğuşu ve Avrupa'ya Yayılımı, Türkiye'de Neolitik

Dönem: Yeni Kazılar-Yeni Bulgular içinde (1-11). İstanbul: Arkeoloji ve Sanat Yayınları.

Rosenberg, M. (2011). 'Hallan Çemi.' M. Özdoğan, N. Başgelen, and P. Kuniholm (Eds.), Neolithic in Turkey Volume 1 içinde (ss.61-78). İstanbul: Archaeology and Art Publications.

Rosenberg, M. vd. (1995). "Hallan Çemi Tepesi: Some Preliminary Observations Concerning Early Neolithic Subsistence Behaviors in Eastern Anatolia."

Anatolica 21, 1995, 1-12.

Rosenberg, M. vd. (1998). "Hallan Çemi, Pig Husbandry, and Post-Pleistocene Adaptations Along the Taurus-Zagros Arc (Turkey)." Paleorient 24/1, 25-41.

Rosenberg, M. ve Davis, M. K. (1992) “Hallan Çemi Tepesi, An Early Aceramic Neolithic Site in Eastern Anatolia: Soma Preliminary Observations Concerning Material Culture." Anatolica 18, 1-18.

Schmidt, K. (2007). 'Göbekli Tepe.' M. Özdoğan, ve N. Başgelen (Eds.), Anadolu'da Uygarlığın Doğuşu ve Avrupa'ya Yayılımı, Türkiye'de Neolitik Dönem: Yeni Kazılar-Yeni Bulgular içinde (115-129). İstanbul: Arkeoloji ve Sanat Yayınları.

Schmidt, K. (2011). 'Göbekli Tepe.' M. Özdoğan, N. Başgelen, and P. Kuniholm (Eds.). Neolithic in Turkey Volume 2 içinde (ss. 41-83). İstanbul: Archaeology and Art Publications.

Stordeur D. ve Ibáñez, J.J., (2008). "Stratigraphie Et Répartition Des Architectures De Mureybet." Ibáñez, Juan José (Ed.). Le site néolithique de Tell Mureybet (Syrie du Nord). En hommage à Jacques Cauvin, BAR International Series (in French), 1843 içinde (ss. 33-94). Oxford: Archaeopress.

Stordeur, D. (2014). "Jerf el Ahmar entre 9500 et 8700 av. J.-C. Un village des débuts de l'agriculture. Une société complexe." C. Manen, T. Perrin et J. Guilaine (eds.). La Transition Neolithique en Méditerranée, ou 
comment des chasseurs devinrent agriculteurs içinde (ss. 27-41). Paris:

Errance.

Taşkıran, H. ve Kartal, M. (2010). "2008 Yılı Ilısu Baraj Gövdesi Alanı 2008 Yüzey Araştırması." 27. Araştırma Sonuçları Toplantısı (III), 233-244.

Türkcan, A. U. (2006). Çanak Çömleksiz Neolitik Dönem Yukarı Mezopotamya Anıtsal Kült Binaları ve Gelişimi. (Yayımlanmamış Doktora Tezi), Hacettepe Üniversitesi Sosyal Bilimler Enstitüsü, Ankara, 2006.

Watkins, T. - Baird, D. J. - Betts, A. (1989). "Qermez Dere and the Early Aceramic Neolithic of N. Iraq." Paléorient 15/1, 19-24

Watkins, T. - Betts, A.V.G. - Dobney, K, - Nesbitt, R.M. (1995). Qermez Dere, Tel Afar: Interim Report No. 3. Edinburgh, University of Edinburgh, Department of Archaeology, Occassional Paper No. 14.

Watkins, T. (2006). Architecture and the Symbolic Construction of New Worlds." E. Banning and M. Chavan (Eds.), Domesticating Space. Studies in Early Near Eastern Production, Subsistence, and Environment 12 içinde (ss. 15-24). Berlin: Ex Oriente.

Yartah, T. (2013). Vie quotidienne, vie communautaire et symbolique a Tell Abr 3 - Syrie du Nord. Donnees et Nouvelles reflextions sur l'horizon PPNA au Nord du Levant 10 000-9 000 BP. (Yayınlanmamış Doktora Tezi). Lyon: Universite de Lyon 2. 


\section{Ekler}

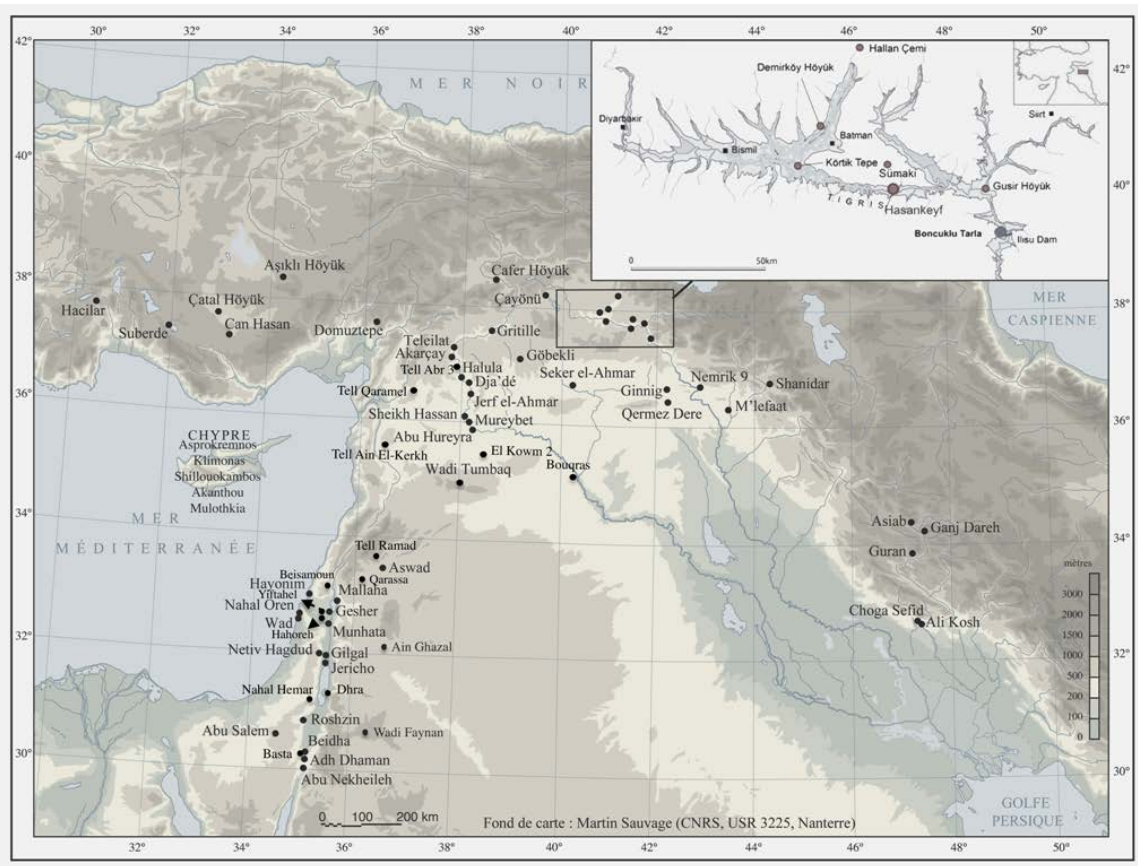

Ek 1: Boncuklu Tarla yerleşim yerinin lokalizasyonu. 


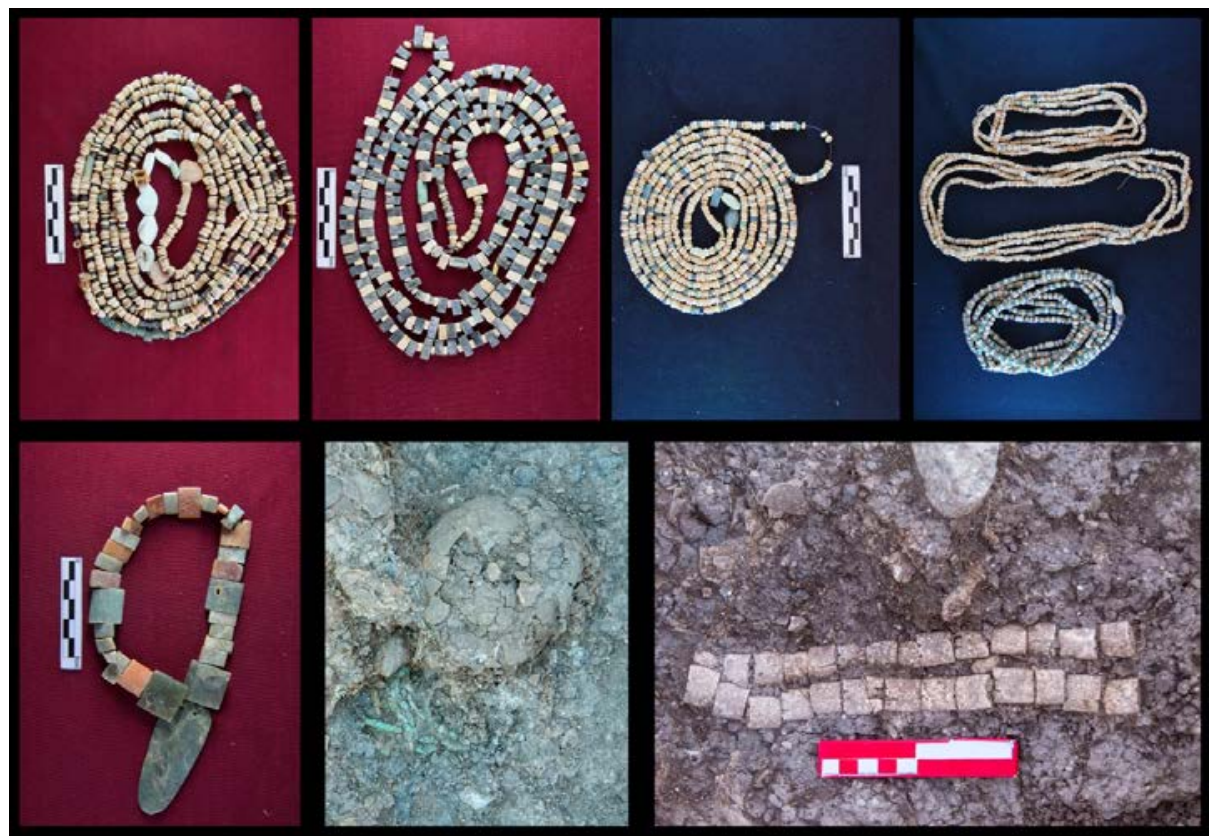

Ek 2: Farklı Mezarlarda ele geçen boncuklar (Kodaş, 2018: Resim 9a; Kodaş ve Erdoğan, 2019: Resim 8a).

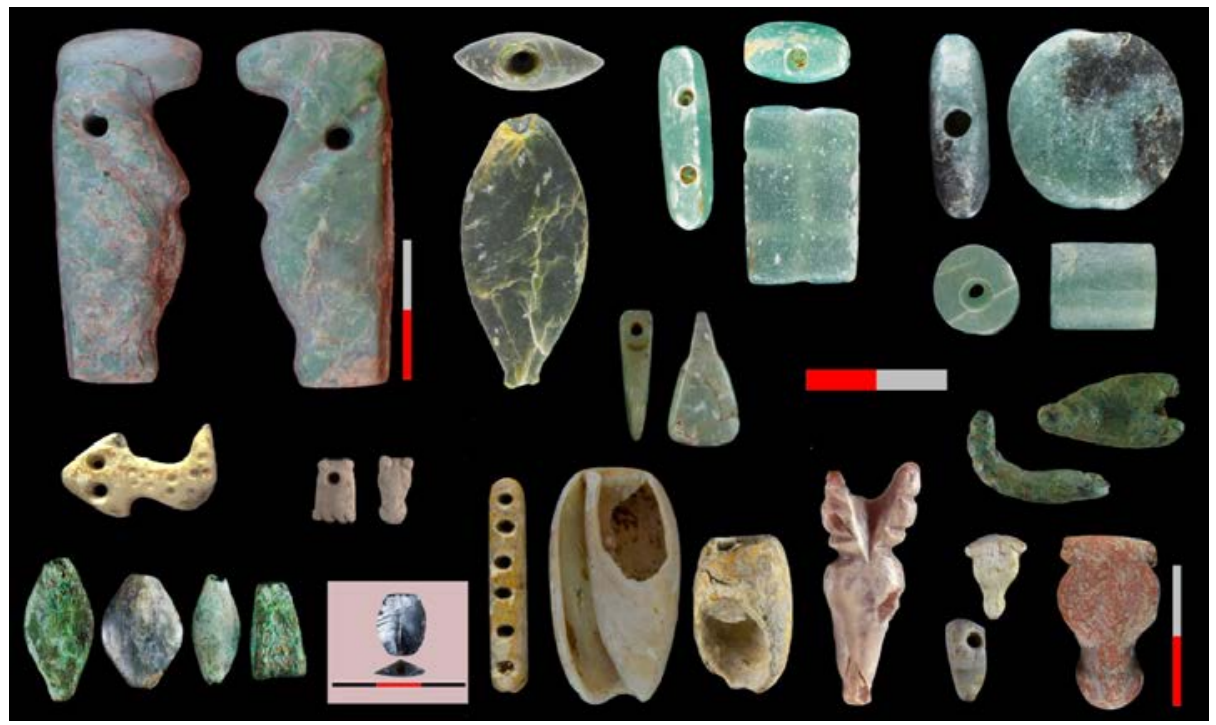

Ek 3: Farklı evrelerde ele geçen boncuk ve pendantlar (Kodaş, 2018: Resim 9b; Kodaş ve Erdoğan, 2019: Resim 8b). 
Bahattin IPEK, Yunus ÇiFTÇi

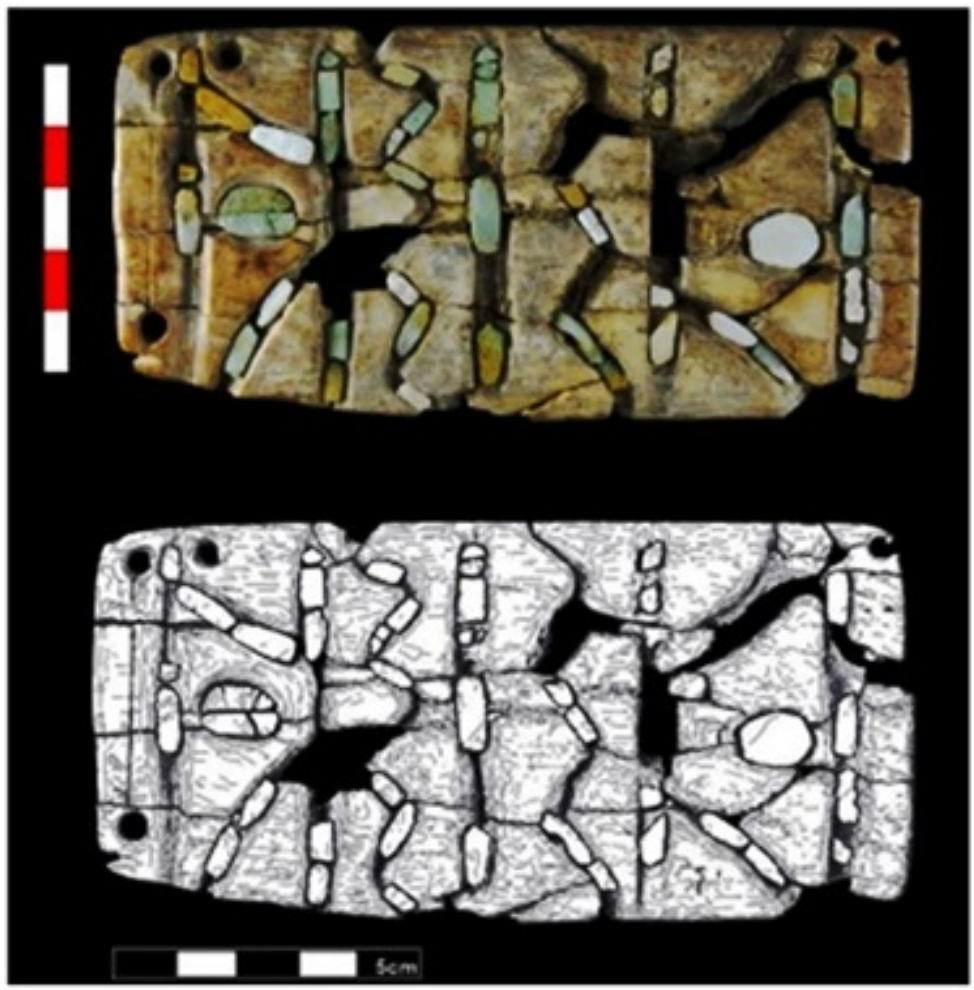

Ek 4: Örümcek Motifi (Boncuklu Tarla Kazı arşivi). 


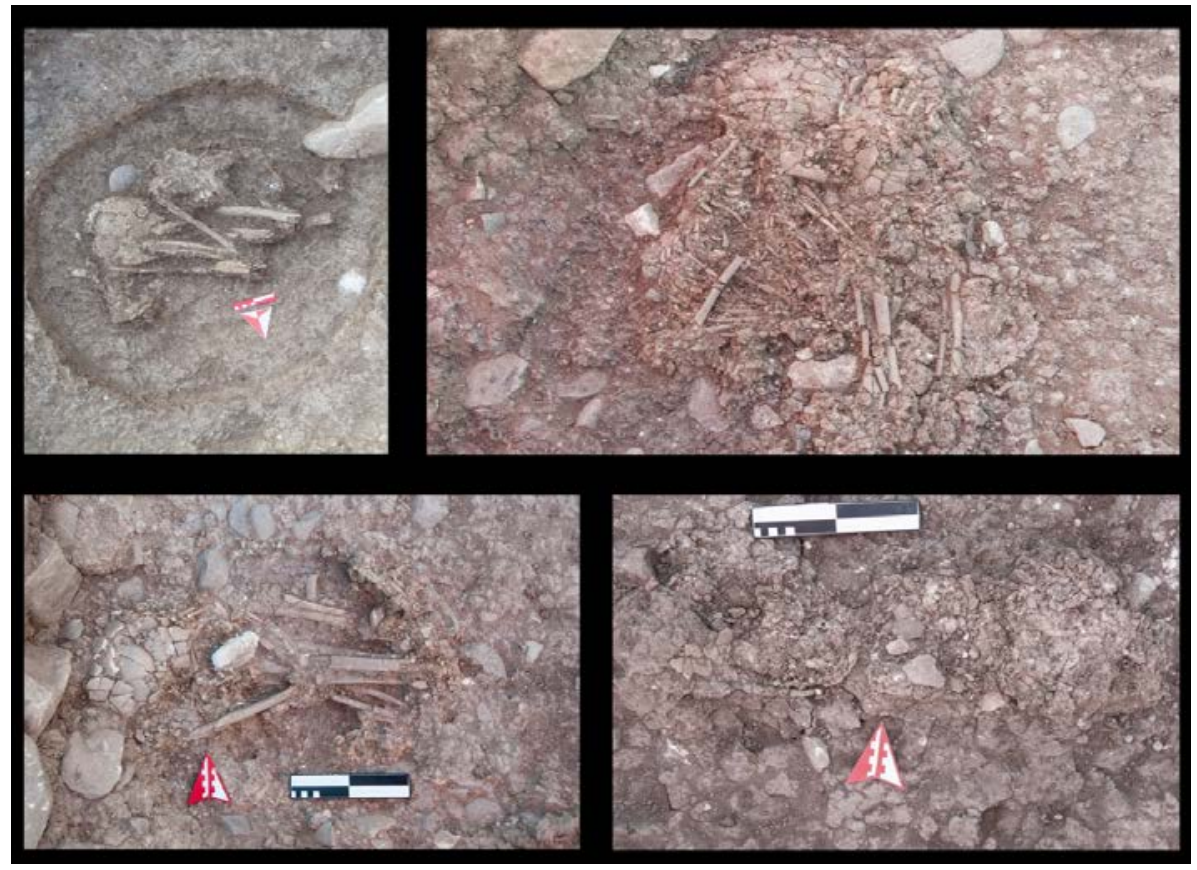

Ek 5: 2017 yılında kazılan bazı mezar örnekleri (Kodaş, 2018: Resim 8; Kodaş ve Erdoğan, 2019: Resim 7). 


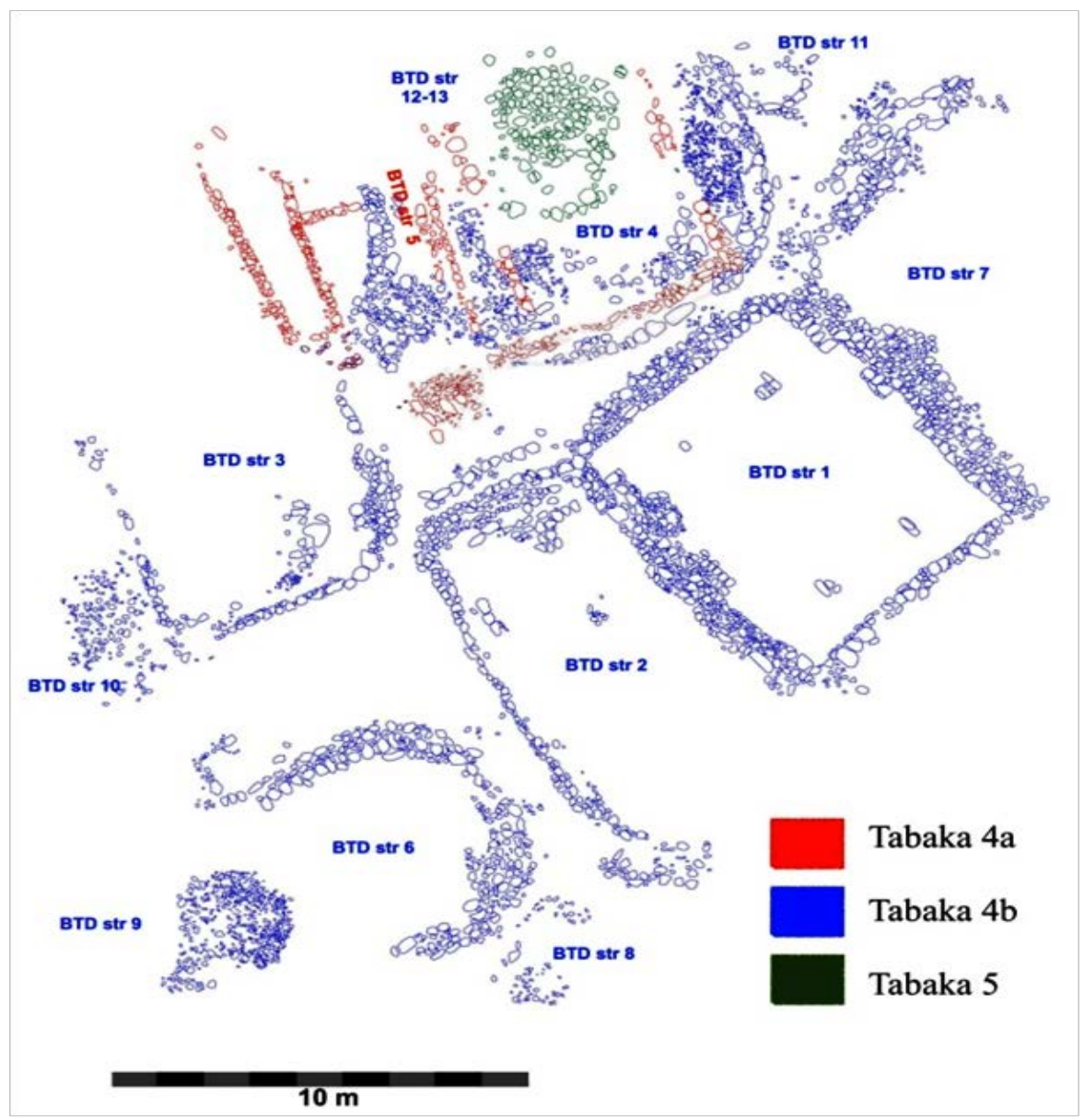

Ek 6: Boncuklu Tarla Doğu Alanı mimari kalıntıları ve tabakaları (Boncuklu Tarla Kazı arşivi). 

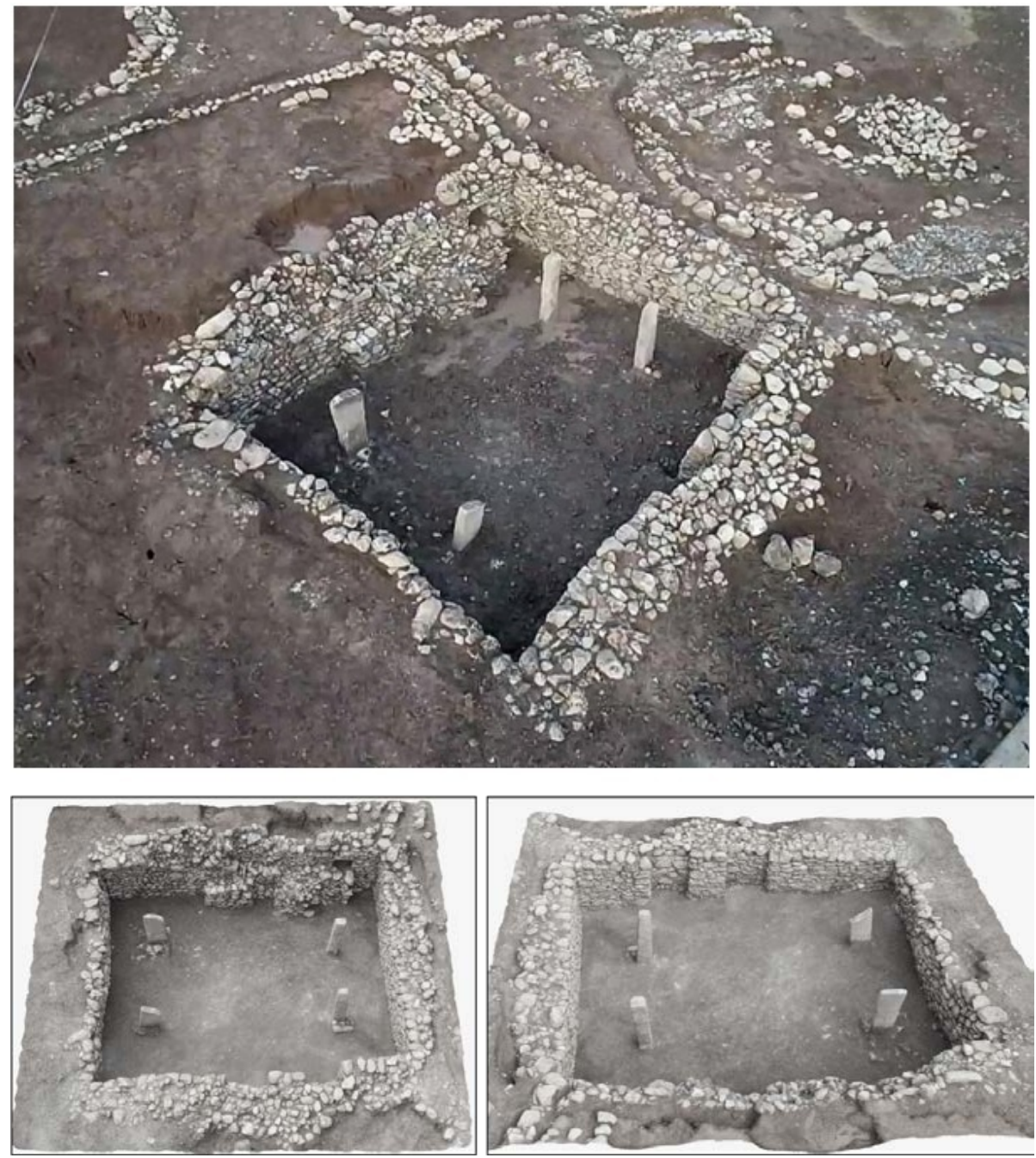

Ek 7: Boncuklu Tarla Kamu Binası (Stelli Bina) (Boncuklu Tarla Kazı Arşivi). 